Article

\title{
Frank Gehry's Self-Twisting Uninterrupted Line: Gesture-Drawings as Indexes
}

\author{
Marianna Charitonidou $1,2,3$ (D) \\ 1 Chair of the History and Theory of Urban Design, Institute for the History and Theory of Architecture (gta), \\ Department of Architecture, ETH Zurich, Stefano-Franscini-Platz 5, CH 8093 Zürich, Switzerland; \\ mchariton@ethz.ch or m.charitonidou@icloud.com \\ 2 School of Architecture, National Technical University of Athens, 42 Patission Street, 10682 Athens, Greece \\ 3 Faculty of Art History and Theory, Athens School of Fine Arts, 42 Patission Street, 10682 Athens, Greece
}

check for updates

Citation: Charitonidou, Marianna. 2021. Frank Gehry's Self-Twisting Uninterrupted Line:

Gesture-Drawings as Indexes. Arts 10: 16. https://doi.org/10.3390/arts1001 0016

Received: 19 December 2020

Accepted: 16 February 2021

Published: 22 February 2021

Publisher's Note: MDPI stays neutral with regard to jurisdictional claims in published maps and institutional affiliations.

Copyright: (C) 2021 by the author. Licensee MDPI, Basel, Switzerland. This article is an open access article distributed under the terms and conditions of the Creative Commons Attribution (CC BY) license (https:// creativecommons.org/licenses/by/ $4.0 /)$.

\begin{abstract}
The article analyses Frank Gehry's insistence on the use of self-twisting uninterrupted line in his sketches. Its main objectives are first, to render explicit how this tendency of Gehry is related to how the architect conceives form-making, and second, to explain how Gehry reinvents the tension between graphic composition and the translation of spatial relations into built form. A key reference for the article is Marco Frascari's 'Lines as Architectural Thinking' and, more specifically, his conceptualisation of Leon Battista Alberti's term lineamenta in order to illuminate in which sense architectural drawings should be understood as essential architectural factures and not merely as visualisations. Frascari, in Eleven Exercises in the Art of Architectural Drawing: Slow Food for the Architects's Imagination, after having drawn a distinction between what he calls 'trivial' and 'nontrivial' drawings - that is to say between communication drawings and conceptual drawings, or drawings serving to transmit ideas and drawings serving to their own designer to grasp ideas during the process of their genesis-unfolds his thoughts regarding the latter. The article focuses on how the 'non-trivial' drawings of Frank Gehry enhance a kinaesthetic relationship between action and thought. It pays special attention to the ways in which Frank Gehrys' sketches function as instantaneous concretisations of a continuous process of transformation. Its main argument is that the affective capacity of Gehry's 'drawdlings' lies in their interpretation as successive concretisations of a reiterative process. The affectivity of their abstract and single-gesture pictoriality is closely connected to their interpretation as components of a single dynamic system. As key issues of Frank Gehry's use of uninterrupted line, the article identifies: the enhancement of a straightforward relationship between the gesture and the decision-making regarding the form of the building; its capacity to render possible the perception of the evolution of the process of form-making; and the way the use of uninterrupted line is related to the function of Gehry's sketches as indexes referring to Charles Sanders Peirce's conception of the notion of 'index'.
\end{abstract}

Keywords: Frank Gehry; lineamenta; line-making; freehand drawings; drawdling; gesture; selftwisting uninterrupted line; Charles Sanders Peirce; Gilles Deleuze; gesture; index

\section{Introduction}

This article examines Frank Gehry's drawing practice, paying special attention to how his preliminary sketches contribute to the genesis of ideas. A characteristic of Gehry's line-making scrutinised here is the use of the self-twisting uninterrupted line (Figure 1). The idea of 'linea serpentinata' in Gehry's practice of line-making has its genealogy in Leon Battista Alberti's thought and Albrecht Dürer's Unterweysung der Messung (Dürer 1525), while a recent precedent is found in Paul Klee's reflection on the serpentine self-twisting line and its interpretation as 'active' (Klee 1953, p. 16). and as the essence of creative thought. Alberti claims that architecture consists of 'lineamenta' —lines-and 'materiale' construction materials and defines the former as 'the precise and correct outline, conceived 
in the mind, made up of lines and angles, perfected in the learned intellect and imagination (Alberti 1988, p. 7). Understanding 'lineamenta' as 'the product of human ingenuity ('ingegno'), and generative process ('natura') portrayed in the materiality of construction' (Frascari 2011), is useful for interpreting architectural drawings as essential architectural factures and not merely as visualisations. Line-making demonstrates the architect's ability to grasp the building's facture. According to Jean-Louis Cohen, Gehry's 'design process changed significantly during 1991 with the introduction of digital tools, coupled with the systematic use of models' (Cohen 2020, p. 15). Two projects in the design process of which this reorientation becomes apparent are the Peter Lewis Residence (1985-1995) in Lyndhurst, Ohio and the Bilbao Guggenheim. However, 'Gehry has continued to rely on sketches, but models-often schematic and rapidly made-have come to play the exploratory role they played for him during his early years of practice' (Cohen 2020, p. 16).

Considering the distinction between the drawings whose function is to transmit ideas - 'trivial' - and those aiding their designer to grasp ideas during their generation process-'non-trivial', we could claim that Gehry's line-making refers to the first category. They function as loci for thought, concern the very condition of architectural experimentation, and belong 'to a specific category of representation that makes architectural thinking possible' (Frascari 2011, p. 9; 2009). The 'non-trivial' drawings of Gehry are understood here as graphesis, that is to say as actions based on factures by which architects actualise future and past architecture into representations. Gehry's sketches, produced through a series of spiralling movements, are captures within the same sketch of a sum of possibilities. The different variations coexist within the same graphesis (Frascari 2009, 2011). Gehry's drawings should be interpreted in relation to the fact that the modes of representation privileged by each architect 'vehicle different ways of constructing assemblages between the designer of architectural representations, their observers and the users of the spatial assemblages after the construction of the architectural artefacts' (Charitonidou 2020, p. 92). In this sense, architectural drawings function as dispositifs. Here, I refer to the concept of dispositif as Michel Foucault understood it, taking also into account the analyses of Gilles Deleuze and Giorgio Agamben concerning Foucault's concept of dispositif. Perceiving a sketch as dispositif is related to the intention to shed light on the interrelations of "heterogeneous systems -object, subject, language and so on -, assuming that the systems are composed of interacting forces that are in a continuous state of becoming, 'always off balance"' (Charitonidou 2020, p. 93; Foucault 1994, p. 299; Deleuze 1989b; 1992, p. 159; Agamben 2006). This means that understanding Gehry's sketches as dispositifs goes hand in hand with aiming to reveal 'the relationships of all the parameters and the interacting forces characterising each parameter' (Charitonidou 2020, p. 93) and to treat them as the most important for understanding what is at stake when Gehry produces them.

The relationships between slow and fast and drawing and thinking are useful for understanding how Gehry's act of drawing gives rise to and elicits his conceptual strategies (Figure 2) (Bechtler 1999). Gehry notes that '[a]s soon as [he] [ . . . ] understands the scale of the building and the relationship to the site [ . . ], as it becomes more and more clear [ ... ] [he] start[s] doing sketches' (Gehry cited in Szalapaj 2014, p. 211). He has underscored that '[b]y the time [he starts] [ ... ] sketching, [he understands] [ ... ] the problem, its scale, context, budget, and constraints' (Gehry in Isenberg 2009, p. 89; Cohen 2001). This remark helps us realise that his 'drawings are very well-informed' and 'drawn with that information in hand', which explains 'why, when you see them at the end [ ... ] they have a lot to do with the finished building' (Gehry in Isenberg 2009, p. 89). Enlightening regarding how his drawings function as tools for thinking are his following words: 'I do a lot of them. I circle the field for a while until I find one I like' (Gehry in Isenberg 2009, p. 90). 


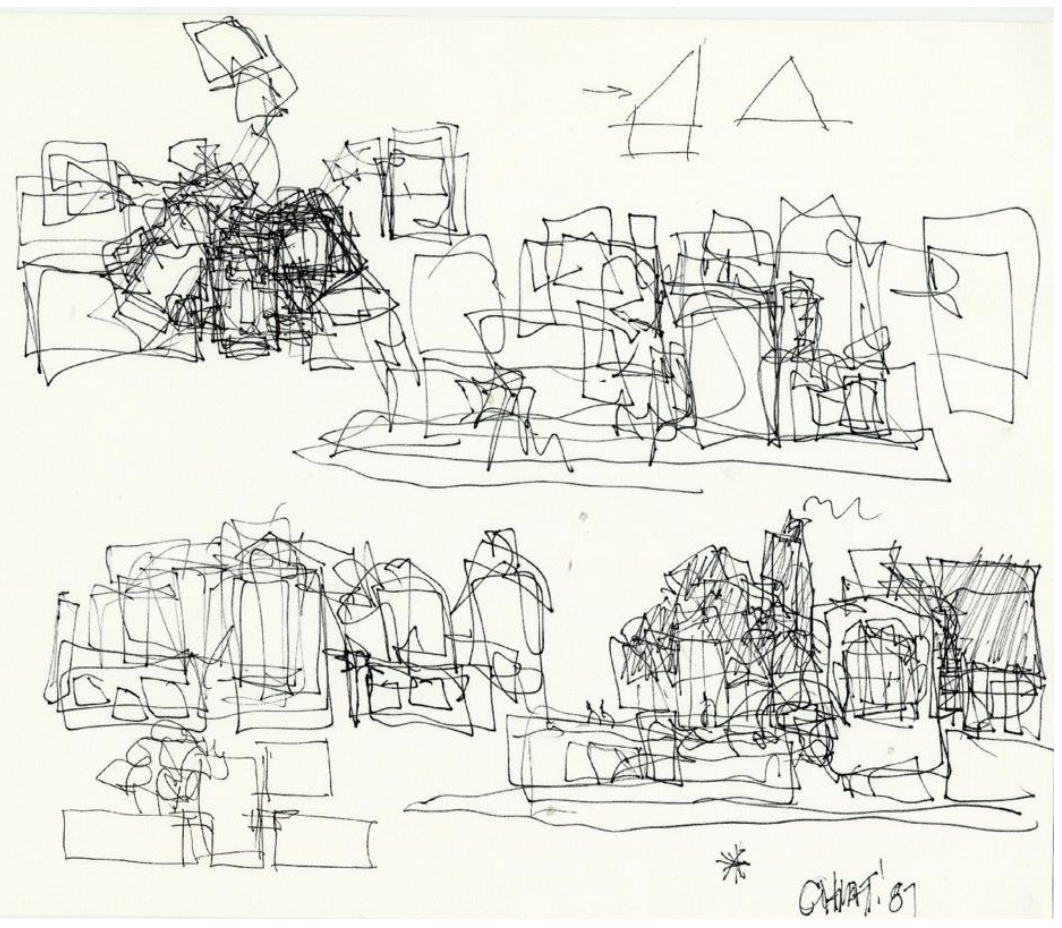

Figure 1. Frank Gehry, 'drawdlings' for the Jay Chiat Residence, Sagaponeck, New York, 1986 (C) Frank O. Gehry. Frank Gehry papers, Series I: Architectural Projects, Getty Research Institute, Los Angeles, CA. Digital image courtesy of the Getty Research Institute Digital Collections.

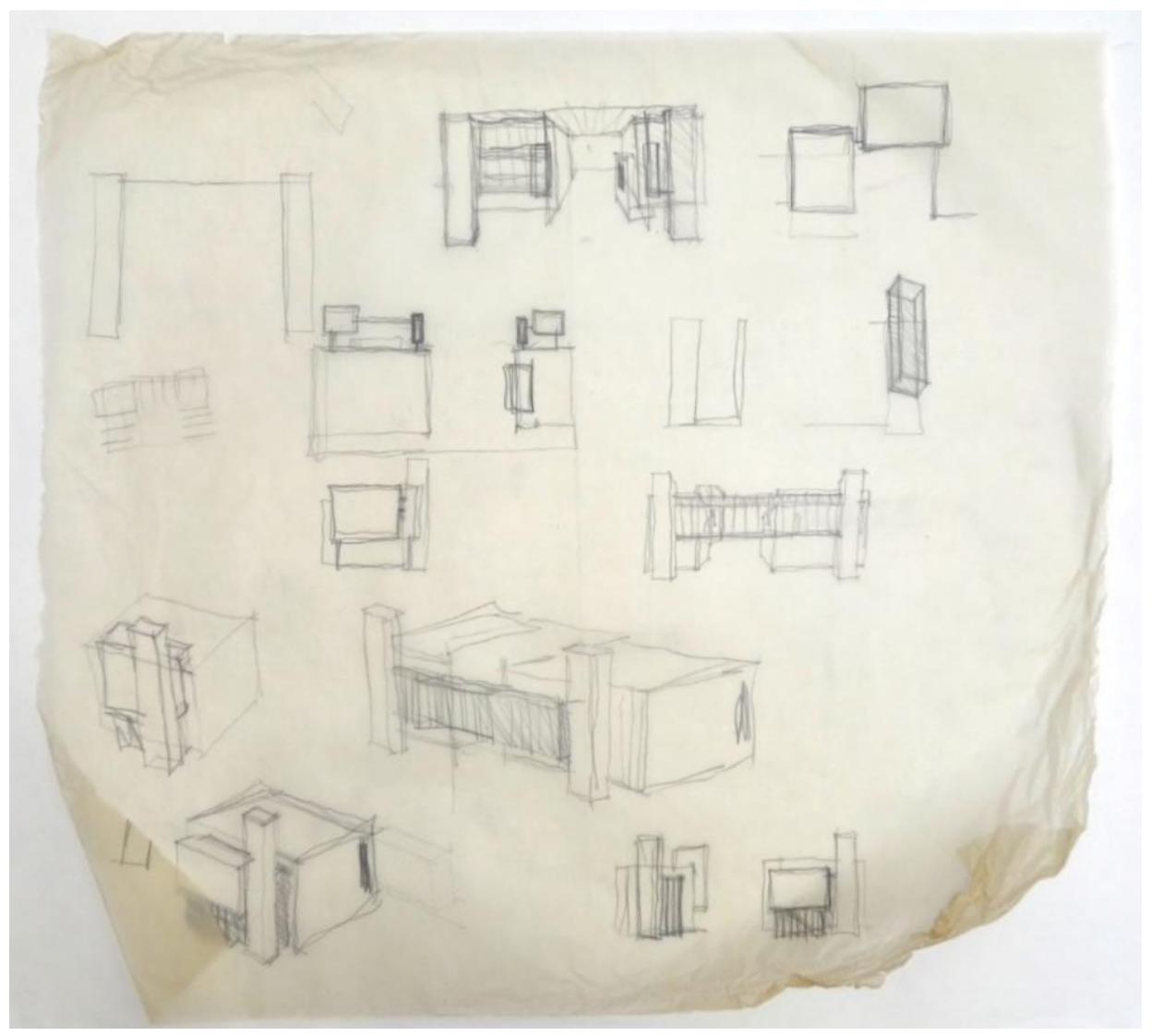

Figure 2. Frank Gehry, Danziger Studio and Residence, Los Angeles, 1964-1965. (C Frank O. Gehry. Frank Gehry papers, Series I: Architectural Projects, Getty Research Institute, Los Angeles, CA. Digital image courtesy of the Getty Research Institute Digital Collections. 


\section{The Single Uninterrupted Line in Frank Gehry's Sketches}

The very force of the single uninterrupted line of Frank Gehry's sketches lies in its capacity to evoke 'the objective self-representation of architecture as the dream shape of the thinking hand' (Bredekamp 2004, p. 20; Ragheb 2001). As key issues of Frank Gehry's use of uninterrupted line, the article identifies the following: first, the enhancement of a straightforward relationship between the gesture and the decision making regarding the form of the building; second, its capacity to render possible the perception of the evolution of the process of form-making; third, the way the use of uninterrupted line is related to the function of Gehry's sketches as indexes referring to Charles Sanders Peirce's conception of the notion of 'index'; and, finally, how Gehry's sketches enhance a kinaesthetic relationship between action and thought.

\subsection{Towards a Straightforward Relationship between Gesture and Decision Making}

Sketching incessantly helps Gehry free his imagination. An aspect of his drawing strategy is the alteration of the rhythm of his hand movement, which results in different qualities of 'lineamenta'. Moving his pen in circles and spirals, Gehry transforms his thinking hand into a tool allowing him to experiment with the very conditions of architecture and spatial perception. All this goes back to the symbolic dimension of the so-called 'first line to a blank surface' and the myth of the 'crucial first stroke' (Bredekamp 2004, p. 11). It brings to mind not only the dynamic freedom revealed by Lucio Fontana's tearing of the surface of canvases, re-inventing the very notion of gesture, but also the spontaneity and the gesture of liberation of Jackson Pollock's drip paintings. Gehry's own line is 'an active participant in the act of drawing and asserts its own creative independence' (Rosand 2013, p. 210), recalling Vilém Flusser's understanding of the creation as a process of 'devising ideas during the gesture of making' (Flusser cited in Gänshirt 2007).

Gehry's gestural aesthetic is characterised by 'self-indulgence' (Foster 2002, p. 40), and his drawings overcome illustration and promote evocation, since their 'aim is not to describe, but to seek and evoke' (Emmons 2019). They promote the 'autonomous objectivity of the building', and, instead of prioritising the subjective viewer, foster the animateness and aliveness of the architectural form. This becomes possible due to the uninterrupted line, which, accelerating and decelerating but without stopping, invites the observer of the drawings to conceive the building form as a sum of possibilities. Gehry 'start[s] drawing [... ] not knowing where it is going ... It's like feeling your way along in the dark, anticipating that something will come out usually'. As 'a voyeur of [ ... ] [his] own thoughts as they develop' (Gehry cited in Bettley et al. 2005, p. 65), he treats his drawing strategies as a mechanism that helps him establish not only a hand-to-eye coordination, but also a mind-to-hand coordination.

\subsection{Gehry's Drawings as Snapshots of a Progressive Concretisation of His Design Ideas}

In the case of Gehry's drawings ' $[t]$ here is a resonance in the ability of the viewer to trace back the line to the gesture, and to understand the transformation of this line into the architectural form' (Lucas 2006, p. 200; Bletter et al. 1986). The correlation of Gehry's drawings with his 'hand movements that seem to think as they execute lines, that circle back upon themselves, that twist and turn in a sequence of S-curves, that paraphrase central perspective' explains their specificity and originality, as well as their capacity to 'convey [their] [ ... ] autonomous objectivity to the observer's imagination' (Bredekamp 2017, p. 169). Gehry compares both his hand-to-eye coordination and his intuitive attempts to concretise his ideas through continually sketching with Michelangelo's effort to find answers when carving his 16th-century sculptural series Slaves. Each of his several sketches of uninterrupted lines is like a snapshot of a continuous transformation which functions as a means to capture his imagination and mental process. Gehry's series of sketches are based on the conviction that each of the successive drawings corresponds to a phase of a progressive concretisation of his design idea. The sum of the drawings enhances 'the training of the language that you've evolved' (Isenberg 2009, p. 88). When he draws, he 
jumps 'from one phase of the process to another in a way that is suggestive and open-ended' (Lindsey 2001, p. 54).

\subsection{Gehry's Drawings as 'Intrinsic Image-Acts': Understanding Architecture in an Image}

This reiterative process of concretising the visual language is 'a kind of 'reverse engineering" (Lindsey 2001, p. 52) based on the production of progressive loose and fast sketches that continually recapture the 'conceptual clarity and energy of the initial gesture' (Lindsey 2001, p. 52). Borrowing Horst Bredekamp's distinction between 'the desire to understand architecture in an image and the desire to understand it as an image', we could claim that Gehry, during the process of drawing, understands architecture in an image. Gehry's drawings, as 'intrinsic image-acts', go beyond central perspective and favour the interplay between architecture and bodily movements. The line-making of Gehry's uninterrupted curves brings to mind Hermann Finsterlin's research on S-curve drawings and Charles Sanders Peirce's effort 'to capture the dynamic architecture of his own thought process' through the visual illustration of more than 40,000 variants of the S-curve.

Peirce drew a distinction between symbolic, iconic, and indexical signs. According to his theory, in the case of indexical signs, the link between the representamen and its object may only be inferred. Despite the fact that, as Michael Leja highlights, in 'Peirce, Visuality, and Art', Peirce's understanding of the notion of the index 'was not applied to the interpretation of art until the late 1960s and 1970s' (Leja 2000, p. 117; Morris 2013). A seminal text of art theory published in the late 1970s in which there is reference to Peirce's understanding of index is Rosalind Krauss's 'Notes on the Index' (Krauss 1977). Peirce's concept of indexicality is valuable for apprehending the bodily dimension of Gehry's line-making since it 'takes into account the performative play of things as measured in relation to living bodies' (Bredekamp 2017, p. 241). Bredekamp's description of Gehry's line-making is telling: 'The strokes themselves—curving, circling, swirling, meandering, occasionally sharply bending and, above all, issuing in serpentine forms-generate a sense of tissue within the internal structure, but in the drawing as a whole prompt, rather, the impression of an entity that vibrates and pulsates' (Bredekamp 2017, p. 242).

In Cinema I: The Movement-Image (Deleuze 1983, 1986) and Cinema II: The Time-Image, Gilles Deleuze refers to six types of images: perception-image, affection-image, impulseimage, action-image, reflection-image, and relation-image (Deleuze 1989a, p. 32; 1985). In parallel, Deleuze draws a distinction between signs of composition, and signs of genesis. In Cinema II: The Time-Image, Deleuze remarks that 'Peirce's strength, when he invented semiotics, was to conceive of signs on the basis of images and their combinations, not as a function of determinants which were already linguistic' (Deleuze 1989a, p. 30; 1985; Elkins 2003; Peirce 1958; Dawkins 2020). In A Thousand Plateaus, Gilles Deleuze and Félix Guattari note that 'indexes, icons, and symbols seem to us to be distinguished by territorialitydeterritorialisation relations, not signifier-signified relations' (Guattari and Deleuze 2007, p. $531 ; 1980)$. They also highlight that the diagram $[. .$.$] seems to have a distinct role,$ irreducible to either the icon or the symbol' (Guattari and Deleuze 2007, p. 531; 1980). Following this argument of Deleuze and Guattari, we could claim that Gehry's sketches function as diagrams. Useful for grasping the implications of understanding sketches as indexes is the remark of Jorge Orozco Esquivel that 'the index forces the attention, points and connects to an object without describing it, and has an existence detached from what it is pointing to' (Orozco Esquivel 2017, p. 227). Another characteristic of the index, which has also been highlighted by Orozco Esquivel, is the fact that its 'direction is not fixed, nor limited' (Orozco Esquivel 2017, p. 227), as it is the case in Gehry's sketches.

\subsection{Promoting a Kinaesthetic Relationship between Action and Thought}

Gehry's freehand drawings are a tool allowing him to think aloud thanks to their speed, freshness, abstractness and spontaneity. What is worth mentioning is the way they stimulate not only visual memory, but also the kinaesthetic relationship between action and thought. Gehry's drawings boost the interactions between thought and representation, 
given that he thinks through drawing, inviting us to grasp how non-trivial sketches make architectural thought approachable. Gehry's conviction that he thinks moving the pen leads to the idea that his drawings 'keep up with the mental aberrations of a brainstorm' (Lindsey 2001, pp. 54, 211, 52-53) thanks to the fact that they are done quickly and semiautomatically. The speed and looseness of their production in almost a single gesture corresponds to the architect's desire to grasp a 'meaningful randomness', and to translate 'the functional demands of a design brief into a graphic form of nonlinear logic' (Edwards 2008, p. 29). Gehry's method as 'in the series of sketches [for the Guggenheim] [ . . ] ranges from wielding the pen with total control to nearly letting the lines flow by themselves, fluid, mobile, punctuated by little jolts, starts, and stops' (Van Bruggen 1998, p. 71). His drawings are the outcome of several energetic gestural short-hands, and it is exactly their lack of precision that makes them capable of generating ideas and of triggering the conceptual process to further evolutions. They are 'characterized by a sense of off-hand improvisation, of intuitive spontaneity', which is reinforced by their capacity to 'convey no architectural mass or weight, only loose directions and shifting spatial relationships' (Szalapaj 2014, p. 212; Migayrou 2014; Lemonier and Migayrou 2015).

Gehry's sketches are known for their 'spontaneity of impulse', and their 'essence of ineffable', and the way they reinvent the tension 'between a system of familiar Platonic solids and a set of spontaneous forms that riff but do not ape this set of familiars' (Sorkin 1999, pp. 28-29). Thanks to this unresolved suspension, they convey a fluidity and a tactile sense, offering a terrain helping him to capture the form of the building, struggling to "'find the building" within his drawings' (Emmons 2019, p. 204). As Maurizio Cecchetti undescores, '[f]or Gehry the principle of combination annihilates the boundary between mental and tactile, and it makes manifest the spirits that agitate the architect's unconscious' (Cecchetti 2011, p. 241). 'The tactical and the tactile can coincide in the instant in which the object, capable of producing sensations, in reality attempts to enlarge the semantic field of an art form beyond the rules that have been all too codified' (Cecchetti 2011, p. 242).

Gehry's endeavour to unearth the 'perfect' form through the incessant reiteration of his line can be observed in his note-referring to the fish, which is at the centre of his thought - that he 'kept drawing it and sketching it and it started to become for me like a symbol for a certain kind of perfection that I couldn't achieve with my buildings'. The fish symbolises his desire to capture perfection and his reiterative never-ending process. As he remarks, 'whenever [he would] [ . . ] draw something and [he] [ . . ] couldn't finish the design, [he would] [ . . . ] draw the fish as a notation' (Gehry cited in Hartoonian 2012, p. 177).

\section{Frank Gehry Vis-à-Vis the Art Scene in Los Angeles in the 1960s, 1970s and 1980s}

To contextualise Gehry's use of the uninterrupted line in his sketches, it is important to relate it to the art scene in Los Angeles, especially to that of the 1960s, 1970s and 1980s (Drohojowska-Philp 2011; Hackman 2015; Mendini 1980; Morgenstern 1982; Bletter et al. 1986; Goldberger 2015). A key reference that would be useful for this purpose is Michael Fallon's Creating the Future: Art and Los Angeles in the 1970s (Fallon 2014). As Jean-Louis Cohen highlights, in Frank Gehry Catalogue Raisonné of the Drawings Volume One, 19541978, to understand Gehry's approach, it is important to take into account the impact of a group of artists who in the 1960s and 1970s exhibited their works at the Ferus and the Dwan galleries such as Wallace Berman, Billy Al Bengston, Ed Moses, Robert Irwin, Kenneth Price, Larry Bell, and Ed Ruscha, among other (Cohen 2020). Cohen also mentions that Gehry designed a house for Ruscha. Moreover, Ruscha and 'Edward Kienholz, who had co-founded the Ferus Gallery with Walter Hopps in 1957, both engaged in a visual commentary critical of Los Angeles during the 1960s, which encouraged Gehry to start looking for inspiration in the most prosaic features of its cityscape' (Cohen 2020, p. 30; 2001). Another artist who had an important impact on Gehry's design process is Jasper Johns, with who he had a close relationship. Gehry's own comments regarding his connection to fine arts and painting are rather revealing: 'I came at architecture through fine art, and 
painting is still a fascination to me. Paintings are a way of training the eye. You see how people compose a canvas. The way Brueghel composes a canvas, or Jasper Johns. I learned about composition from their canvases. I picked up all those visual connections and ideas' (Gehry in Rappolt and Violette 2004, p. 7).

Despite the fact that he started intensively using the black-and-white fast and loose doodles as the mechanism par excellence of brainstorming in the 1980s, he was already using methods based on abstractness from as early as the 1960s, as can be seen in his initial sketches for Danziger studio/residence (1964-1965) (Figure 2), whose abstractness and disposition of different drawings on the same sheet of paper reminds us of one of his initial sketches for his own residence in Santa Monica (1978) (Cohen 2020, pp. 500-14; Friedman 2013). Gehry himself relates 'the shift from orthogonal to perspectival' in his work to his encounter with the American Abstract Geometric painter Ron Davis, for whom Gehry designed a studio/residence in Malibu (1968-72) and who at the time of their first exchanges 'was doing paintings that were about perspectival constructions'. What intrigued Gehry was the fact that Davis 'could draw but he could not make them; he could not turn them into three-dimensional objects' (Gehry cited in ZaeraPolo 2006, p. 19).

Gehry's avoidance of pictorial drawings brings to mind Walter Benjamin's critique of the pictorial construction of architecture (Benjamin 1999, pp. 669-70). Benjamin employed the distinction between optical and tactical, drawing upon Alois Riegl's approach and art historian Carl Linfert's interpretation of the latter, and shed light on how drawings can promote a multi-perspectival perception of space and to render explicit the limits of central perspective. Gehry's attempts to grasp the form as an organic continuum through fast hand-drawing could be seen as a case that elucidates Benjamin's arguments. They overcome the restraints of perception when space is represented using a single viewpoint, as is the case in central perspective.

\subsection{Juxtaposing the Different Drawings on the Same Sheet of Paper: Frank Gehry's Sketches for Peter Lewis Residence, Jay Chiat Residence, and Winton Residence Guest House}

The neologism 'drawdling' (Maclagan 2014, pp. 55, 60, 74) used by David Maclagan to describe Thom Mayne's drawing strategy could also be used for Gehry's line-making, whose doodles are reiterated and transformed progressively through their successive repetitions as a never-ending start over. The main argument of this text is that the distinctive force of Gehry's practice of drawing, or 'drawdling', lies in the way each of his sketches functions as snapshots or instantaneous concretisation of a continuous process of transformation. This becomes evident in his sketches for the Jay Chiat Residence in Sagaponeck, New York (1986) (Figure 3), but also in those for the Winton Residence Guest House (1983-1987) (Arnell and Bickford 1985). A common characteristic of Gehry's sketches for these projects is the choice of Gehry to draw on one single sheet diverse variants of the same project both in plan and in elevation (Figures 4 and 5). This tendency to explore visually simultaneously the various views of a project should be interpreted in conjunction with his intention to address in a non-hierarchical way both the functional and morphological features of the building. Another trait of Gehry's design strategies that is worth-mentioning is his tendency to assemble individual programmatic elements into a programmatic whole without restraining his design approaches through the use of conventional programmatic units. This becomes apparent in the case of the Winton Residence Guest House, where 'the programmatic elements of the project are embodied as individual pieces and then collected together as a whole' (Rappolt and Violette 2004, p. 46). We can understand how much importance Gehry gave to this process of assembling in an inventive way the programmatic elements in a synthetic whole in his sketches, which constitute numerous alternatives of assembling these elements. His sketches for this project can help us realise how much attention he paid to the creation of 'a cluster of objects placed together in a tight complex' (c 46).

The combination of several versions of the same project on one sheet of paper is a characteristic of many of his sketches for various projects, and invites the viewers to interpret his drawings as nodes of a complex system. This system consists of reiterated 
captures through single-gesture sketches, and helps us grasp their strength not only as an application of brainstorming tools to the design process, but also as dynamic semiotic mechanisms. Seeing these drawings, one understands that, in Gehry's case, it is not the single drawing that matters, but the act or the practice of drawing that enables him to proceed from spontaneity towards concretisation. Seeing Gehry's sketches shown in Figures 3-5, it becomes evident that the choice of Gehry to represent on the same sheet of paper the different drawings of the same building goes hand-in-hand with his intention to grasp in a holistic way what would be the impact of a specific decision concerning the form-making of a building for all the views of the building and its plans.

The juxtaposition of the different drawings on the same sheet of paper makes the process of brainstorming into a tool allowing the architect to reach beyond the limits of conventional, static modes of representation. In parallel, it reveals Gehry's wish to develop a holistic view of all the aspects of the project, and his care about the relationships of the components. The way he represented the project goes hand in hand with his intention to promote the dynamic relationships of the components of the building. Although the program of the Winton Residence Guest House concerned the grouping of one-room buildings differentiated by cracks, Gehry's experimentation shows that even with a relatively simple program it is possible to produce complex spatial qualities. In his drawings, one can easily understand that the main challenge for him was the creation of effectual relationships between the different components. His continuous line-making, the overlapping of the outlines of different volumes and his choice to represent the assemblage of different components of the buildings from different viewpoints are all strategies that serve to convert Gehry's 'drawdlings' into a mechanism capable of applying brainstorming. This does not only concern the sculptural qualities of the building but, more importantly, contributes to the fusion of the different programmatic entities into a complex system of movements throughout the building.

Despite the fact that the unbuilt Lewis Residence is more known for its use of computer software to render and fabricate the model's sculptural elements, the sketches that Gehry produced for it are also characterised by the intention to conceive the sculptural form as an assemblage. This project is related to the shift of Gehry's design processes towards a new phase based on the extensive use of digital tools and computer-aided three-dimensional interactive application software such as CATIA 3D model, which was used in order to produce perspective views. Gehry also places particular emphasis on the combination of drawings and physical models during the design process. In most of the cases the design process evolves according to the following sequence: first, Gehry produces some preliminary sketches; then his assistants fabricate a physical model based on his sketches, and Gehry creates more drawings based on this spiral process. Since the late 1980s and especially since the design of Lewis Residence to the physical working models that are used as an important step during the preliminary design process has been added the extensive use of digital 3D models, which are produced taking as their point of departure Gehry's initial sketches. What is at the centre of Gehry's design process is ' $[t]$ he incessant feedback loops between sketches, three-dimensional computer simulations, built models and engineering drawings' (Lynn 2017, p. 295).

\subsection{Challenging the Dichotomy between Morphological and Functionalist Aspects}

In contrast with the most dominant interpretations of Frank Gehry's approach, which shed light on the morphological aspects of Frank Gehry's buildings, neglecting his concerns about how the building functions, what I argue here is that through his use of the single uninterrupted line and the juxtaposition of the different sketches concerning the same building on a single sheet of paper, Gehry challenges the distinction between the plans, the views, and the sections and the tendency of certain architects of prioritising the one kind of drawing over the other. In other words, Gehry treats the plans, the views and the sections as having the same status. This tendency of Gehry to treat in a balanced way the different drawings without hierarchising them also implies his opposition to a 
rigid distinction between the functionalist and morphological issues of architecture. This hypothesis is further reinforced by Jean-Louis Cohen's remark that, in Gehry's design process, 'the extensive research for exterior form begin, using models of different scale' begins '[o]nly after [a] [ ... ] quasi-functionalist phase'. More specifically, this phase is characterised begins 'by dissecting programmatic elements into singular components, and then reassembling them to adjust for hierarchies and adjacencies' (Cohen 2020, p. 18).

Another characteristic of Gehry's conceptual strategies, which is apparent in the sketches illustrated in Figures 3-5 is to challenge the tendency of architects to design first the contour of a building and then divide the space into its units, which correspond to the different functions. This is very evident in the case of his sketches for the Winton Residence Guest House. Gehry started working on the Winton Residence Guest House in 1983. This project concerned the extension of an existing house designed in the early 1950s by Philip Johnson in Wayzata, Minnesota. The main design gesture of Gehry's proposal for this project was the grouping of a series of forms around a tall central living space. Opposing himself to such a conventional way of designing a plan, Gehry seems to start sketching from the centre of a building towards its contour, conceiving the plan as an assemblage of the functional units of the building and trying to bring these different units into an assemblage. Useful for understanding the significance of functional aspects for Gehry's design process are his following remark regarding this project:

Solving all the functional problems is an intellectual exercise [ ... ] And I make a value out of solving all those problems. Dealing with the context and he client and finding my moment of truth after I understand the problem. If you look at our process [ ... ] you see models that show the pragmatic solution to the building without architecture. Then you see the study models that go through leading to the final scheme. We start with shapes, sculptural forma. Then we work into the technical stuff (Rappolt and Violette 2004, p. 52; Knight 2000)

In order to better grasp how Gehry conceives the forms of his buildings and their plans, views and sections as assemblages, it would be useful to bring to mind not only Felix Guattari and Gilles Deleuze's conception of assemblage in A Thousand Plateaus (Guattari and Deleuze 1980, 2004), but also Robert Rauschenberg's works. As Martino Stierli mentions, in Montage and the Metropolis: Architecture and the Representation of Space, that 'assemblage [... ] stands for a non-hierarchical order where objects/thoughts are placed next to each other rather than vertically aligned' (Stierli 2018, p. 272; Brown 2020). Guattari and Deleuze define the assemblage as follows: 'An assemblage has neither base nor superstructure, neither deep structure nor superficial structure; it flattens all of its dimensions onto a single plane of consistency upon which reciprocal presuppositions and mutual insertions play themselves out' (Guattari and Deleuze 2004, p. 100; 1980). Seeing Gehry's sketches we cannot but think that they are characterised by a non-hierarchical order, which brings to mind Rauschenberg's Combine. As Jean-Louis Cohen highlights, Frank Gehry met Robert Rauschenberg in 1950. Twelve years later, in 1962, Rauschenberg's Combines, exhibited at the Ferus Gallery, had an important impact on Gehry's thought (Cohen 2020; McKenna 2009). A characteristic of Rauschenberg's three-dimensional assemblies 'combines' is their hybrid status as 'painting(s) playing the game of sculpture' (Tomkins 2005). In a similar way, Gehry's buildings play the game of sculpture. 

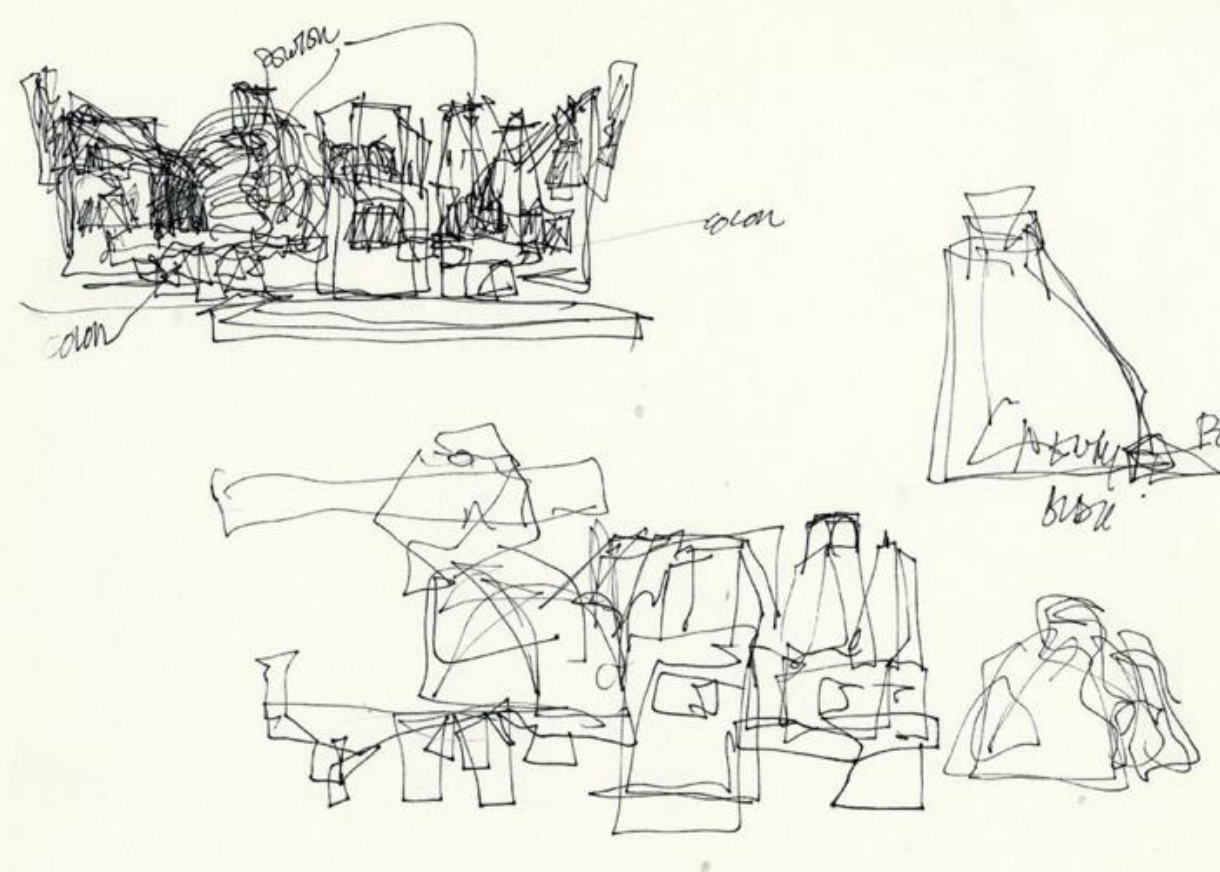

Figure 3. Frank Gehry, project sketch for Chiat Residence, Sagaponeck, New York, 1986 @ Frank O. Gehry. Frank Gehry papers, Series I: Architectural Projects, Getty Research Institute, Los Angeles, CA. Digital image courtesy of the Getty Research Institute Digital Collections.

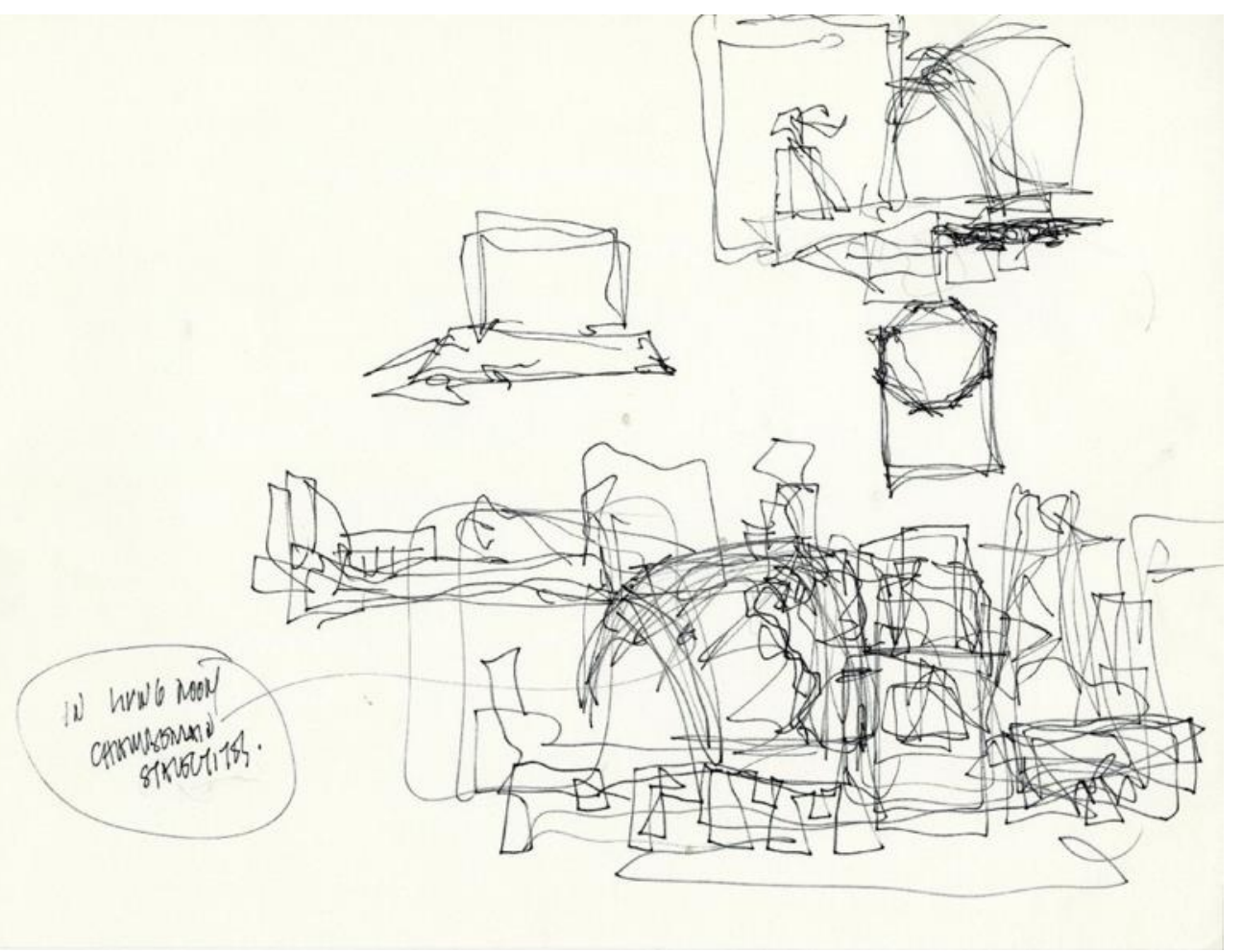

Figure 4. Frank Gehry, project sketch for Chiat Residence, Sagaponeck, New York, 1986 @ Frank O. Gehry. Frank Gehry papers, Series I: Architectural Projects, Getty Research Institute, Los Angeles, CA. Digital image courtesy of the Getty Research Institute Digital Collections. 


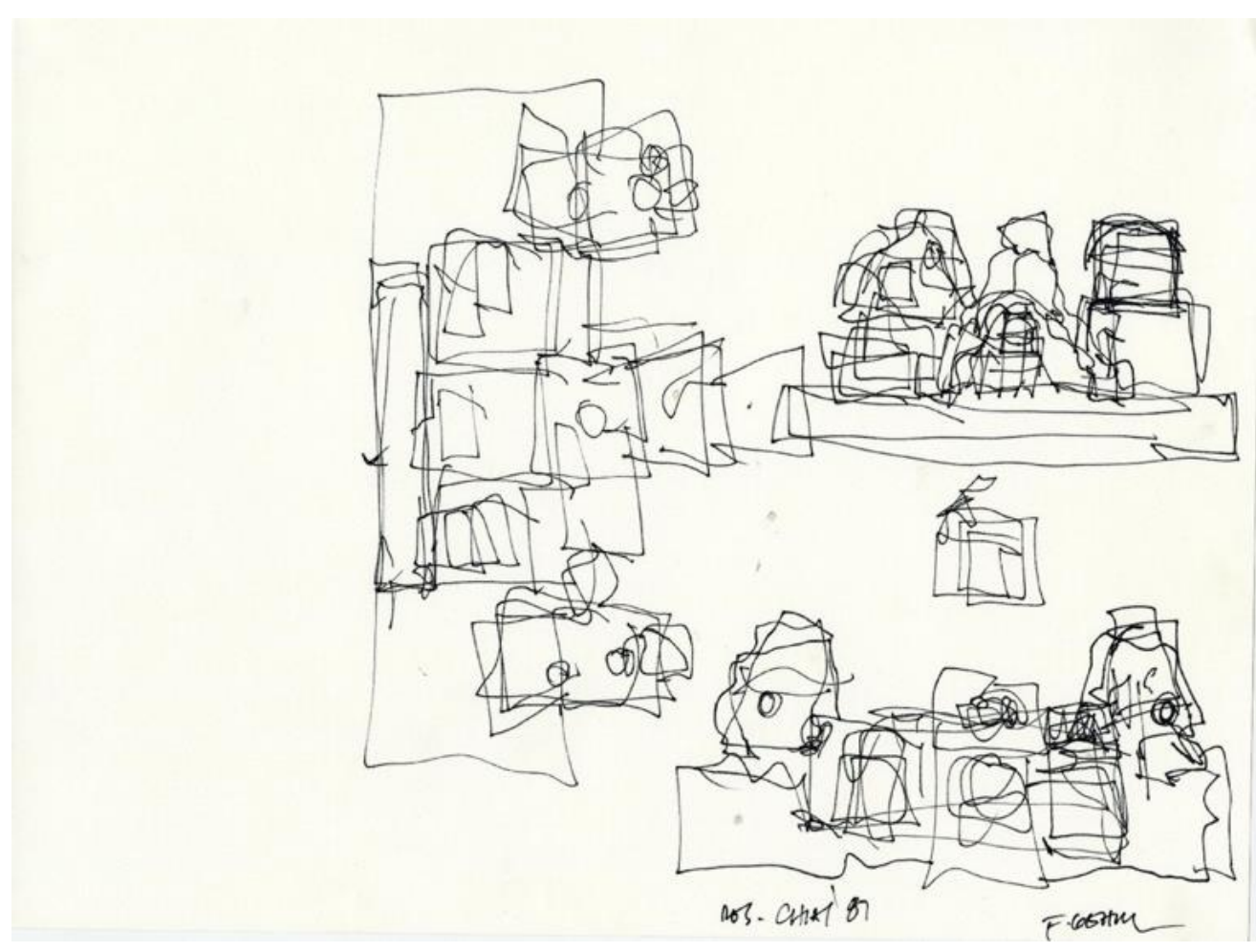

Figure 5. Frank Gehry, project sketch for Chiat Residence, Sagaponeck, New York, 1986 @ Frank O. Gehry. Frank Gehry papers, Series I: Architectural Projects, Getty Research Institute, Los Angeles, CA. Digital image courtesy of the Getty Research Institute Digital Collections.

\section{Conclusions}

The way Gehry treats drawing as a design tool is based on the reinvention of the tension between graphic composition and the translation of spatial relations into built form. The mis-en-suspension of this tension converts Gehry's drawings from visual illustrations serving to construct forms into tools of distribution of spatial qualities, always strengthening their non-trivial quality, pushing his sketches and their uninterrupted lines to acquire an ontological status. One could use the term 'doodle', which emerged in the mid-1920s, to describe Gehry's gestural drawings, given that the idea of the transformational is at the very centre of his sketching activity. Even if 'scribbles' - which have 'a specifically modern, psychological slant' (Maclagan 2014, p. 55) and play 'out a dynamic relation between order and disorder' (Maclagan 2014, p. 60)-differ from 'doodles' due to the fact that the latter are generally more elaborate than the former, while both are produced in a distracted state, have affinities with the so-called automatic drawing, and are based on spontaneity and improvisation.

Gehry deliberately dives into this transformational process to discover what forces him to think, always embarking into an adventure that is situated between sensibility and thought. In contrast with Roger Connah, who has claimed that 'Gehry reinvents the Merzbau, the dada suicide in architecture' (Connah 2001, p. 116), I would claim that Gehry reinvents the genesis and life of architectural thought, converting intuition into its very material. For him ' $[\mathrm{t}]$ he dream, as you prepare the drawings [ ... ] has to come out the other end with the passion and feeling you invested in it' (Gehry cited in Marshall 2001, p. 64). His 'drawdlings' reveal the virtue of architectural thought to be conceived as the agent of a continuous metamorphosis and an unceasing interaction between spontaneity and concretisation. The way Gehry reinvents, through his 'drawdlings', the tension between graphic composition and the translation of spatial relations into built form, reveals the status of his drawings as indexes between the conception of architecture and its actual construction. 
Funding: This research received no external funding.

Institutional Review Board Statement: Not applicable.

Acknowledgments: The Figures included in this article are part of Frank Gehry papers, Series I: Architectural Projects, Getty Research Institute, Los Angeles, CA. I am authorized to include them in my article. I am thankful to Getty Research Institute that made them available through Digital Collections.

Conflicts of Interest: The author declares no conflict of interest.

\section{References}

Agamben, Giorgio. 2006. Che cos'è un dispositivo? Milan: Notte Tempo.

Alberti, Leon Battista. 1988. On the Art of Building in Ten Books. Translated by Joseph Rykwert, Neil Leach, and Robert William Tavernor. Cambridge: The MIT Press.

Arnell, Peter, and Ted Bickford, eds. 1985. Frank Gehry, Buildings and Projects. New York: Rizzoli.

Bechtler, Christina, ed. 1999. Frank Gehry-Kurt Forster [Art and Architecture in Discussion]. Ostfildern: Cantz.

Benjamin, Walter. 1999. Rigorous Study of Art. In Selected Writings, 1927-34. Edited by Michael W. Jennings, Howard Eiland and Gary Smith. Translated by Thomas Y. Levin. Cambridge: Belknap Press, pp. 669-70.

Bettley, Alison, David Mayle, and Tarek Tantoush, eds. 2005. Operations Management: A Strategic Approach. London: Sage Publications.

Bletter, Rosemarie Haag, Henry N. Cobb, Coosje van Bruggen, Mildred Friedman, Joseph Giovannini, Thomas S. Hines, Pilar Viladas, and Frank Gehry. 1986. The Architecture of Frank Gehry. New York: Rizzoli.

Bredekamp, Horst. 2004. Frank Gehry and the Art of Drawing. In Gehry Draws. Edited by Mark Rappolt and Robert Violette. Cambridge: MIT Press.

Bredekamp, Horst. 2017. Image Acts: A Systematic Approach to Visual Agency. Boston and Berlin: De Gruyter.

Brown, Bill. 2020. Re-Assemblage (Theory, Practice, Mode). Critical Inquiry 46: 259-303. [CrossRef]

Charitonidou, Marianna. 2020. Architecture's Addressees: Drawing as Investigating Device. Villardjournal 2: 91-111. [CrossRef]

Cecchetti, Maurizio. 2011. For Sensitive Skin: On the Transformation of Architecture into Design. Annali d'Italianistica, Italian Critical Theory 29: 237-52.

Cohen, Jean-Louis. 2001. Frankly Urban: Gehry from Billboards to Bilbao. In Frank Gehry, Architect. Edited by J. Fiona Ragheb. New York: Solomon R. Guggenheim Museum, pp. 322-36.

Cohen, Jean-Louis. 2020. Frank Gehry Catalogue Raisonné of the Drawings Volume One, 1954-78. Paris: Cahiers d'art/Staffan Ahrenberg.

Connah, Roger. 2001. How Architecture Got Its Hump. Cambridge: The MIT Press.

Dawkins, Roger. 2020. From the perspective of the object in semiotics: Deleuze and Peirce. Semiotica 233: 1-18. [CrossRef]

Deleuze, Gilles. 1983. Cinéma 1, L'image-Mouvement. Paris: Les éditions de Minuit.

Deleuze, Gilles. 1985. Cinéma 2, L'image-Temps. Paris: Les éditions de Minuit.

Deleuze, Gilles. 1986. Cinema I: The Movement-Image. Translated by Hugh Tomlinson, and Barbara Habberjam. London and New York: Bloomsburry Academic.

Deleuze, Gilles. 1989a. Cinema II: The Time-Image. Translated by Hugh Tomlinson, and Robert Galeta. London and New York: Bloomsburry Academic.

Deleuze, Gilles. 1989b. Qu'est-ce qu'un dispositif ? In Michel Foucault philosophe: Rencontre internationale Paris 9, 10, 1 Janvier 1988. Paris: Éditions du Seuil.

Deleuze, Gilles. 1992. What is a Dispositif? In Michel Foucault, Philosopher. Edited by Timothy J. Armstrong. Hemel Hempstead: Harvester Wheatsheaf.

Drohojowska-Philp, Hunter. 2011. Rebels in Paradise. The Los Angeles Art Scene and the 1960s. New York: Holt \& Co.

Dürer, Albrech. 1525. Underweysung Der Messung. Nuremburg: Hieronymus Andreas Formschneider.

Edwards, Brian. 2008. Understanding Architecture through Drawing. New York: Taylor and Francis.

Elkins, James. 2003. What Does Pierce's Sign Theory Have to Say to Art History? Culture, Theory and Critique 44: 5-22. [CrossRef]

Emmons, Paul. 2019. Drawing Imagining Building: Embodiment in Architectural Design Practices. London and New York: Routledge.

Fallon, Michael. 2014. Creating the Future: Art and Los Angeles in the 1970s. Berkeley: Counterpoint Press.

Foster, Hal. 2002. Design and Crime: (and Other Diatribes. London and New York: Verso.

Foucault, Michel. 1994. Dits et écrits. 1954-1988, vol. III: 1976-1979. Paris: Éditions Gallimard.

Frascari, Marco. 2009. Lines as Architectural Thinking. Architectural Theory Review 14: 200-12. [CrossRef]

Frascari, Marco. 2011. Eleven Exercises in the Art of Architectural Drawing: Slow Food for the Architect's Imagination. London and New York: Routledge.

Friedman, Mildr. 2013. Frank Gehry: The Houses. New York: Rizzoli.

Gänshirt, Christian. 2007. Tools for Ideas: Introduction to Architectural Design. Basel, Boston and Berlin: Birkhäuser.

Goldberger, Paul. 2015. Building Art; the Life and Work of Frank Gehry. New York: Alfred A.

Guattari, Felix, and Gilles Deleuze. 1980. Capitalisme et Schizophrénie II: Mille Plateaux. Paris: Les éditions de Minuit. 
Guattari, Felix, and Gilles Deleuze. 2004. Thousand Plateaus: Capitalism and Schizophrenia. Translation and Forward by Brian Massumi. London and New York: Continuum.

Guattari, Felix, and Gilles Deleuze. 2007. A Thousand Plateaus: Capitalism and Schizophrenia. Translation and Forward by Brian Massumi. London and Minneapolis: University of Minnesota Press.

Hackman, William. 2015. Out of Sight: The Los Angeles Art Scene of the Sixties. New York: Other Press.

Hartoonian, Gevork. 2012. Architecture and Spectacle: A Critique. London: Ashgate.

Isenberg, Barbara, ed. 2009. Conversations with Frank Gehry. New York: Knopf.

Klee, Paul. 1953. Pedagogical Sketchbook. Translated by Sibyl Moholy-Nagy. New York: Frederick A. Praeger.

Knight, Christopher. 2000. Full of Generosity. In Frank Gehry, Frank O. Gehry: The Architect's Studio. Seattle: Henry Art Gallery.

Krauss, Rosalind. 1977. Notes on the Index. October 3: 68-81.

Leja, Michael. 2000. Peirce, Visuality, and Art. Representations 72: 97-122. [CrossRef]

Lemonier, Aurélien, and Frédéric Migayrou, eds. 2015. Frank Gehry. Los Angeles: LACMA.

Lindsey, Bruce. 2001. Digital Gehry: Material Resistance Digital Construction. Basel, Boston and Berlin: Birkhäuser.

Lucas, Raymond. 2006. The Sketchbook as Collection: A Phenomenology of Sketching. In Recto Verso: Redefining the Sketchbook. Edited by Angela Bartram, Nader El-Bizri and Douglas Gittens. London and New York: Routledge.

Lynn, Greg. 2017. Going Native: Notes on Selected Artifacts from Digital Architecture at the End of the Twentieth Century. In When Is the Digital in Architecture. Edited by Andrew Goodhouse. Berlin and Montreal: Sternberg Press/Canadian Centre for Architecture, pp. 279-334.

Maclagan, David. 2014. Line Let Loose: Scribbling, Doodling and Automatic Drawing. London: Reaktion.

Marshall, Alex. 2001. How to Make a Frank Gehry Building. New York Times, April 8, 64.

McKenna, Kristine. 2009. The Ferus Gallery: A Place to Begin. Göttingen: Steidl.

Mendini, Alessandro. 1980. Dear Frank Gehry. Domus 604: 1.

Migayrou, Frédéric, ed. 2014. Frank Gehry. The Fondation Louis Vuitton. Orléans: Hyx.

Morgenstern, Joseph. 1982. The Gehry Style. New York Times, May 16, 48.

Morris, Sharon. 2013. Peirce: Re-Staging the Sign in the Work of Art. Recherches sémiotiques/Semiotic Inquiry 33: 177-204. [CrossRef]

Orozco Esquivel, Jorge. 2017. Indexical Architecture: Prominent Positions, Applications and the Web. Ph.D. dissertation, ETH Zurich, Zurich, Switzerland.

Peirce, Charles Sanders. 1958. Collected Writings (8 Vols.) (1931-58). Edited by Charles Hartshorne, Paul Weiss and Arthur W Burks. Cambridge: Harvard University Press.

Ragheb, J. Fiona, ed. 2001. Frank Gehry, Architect. New York: Solomon R. Guggenheim Museum.

Rappolt, Mark, and Robert Violette, eds. 2004. Gehry Draws. Cambridge: MIT Press.

Rosand, David. 2013. Time Lines. In Moving Imagination: Explorations of Gesture and Inner Movement. Edited by Helena de Preester. Amsterdam and Philadelphia: John Benjamins Publishing Company.

Sorkin, Michael. 1999. Frozen Light. In Gehry Talks: Architecture + Process. Edited by Mildred Friedman. New York: Rizzoli.

Stierli, Martino. 2018. Montage and the Metropolis: Architecture and the Representation of Space. London and New Haven: Yale University Press.

Szalapaj, Peter. 2014. Contemporary Architecture and the Digital Design Process. London and New York: Routledge.

Tomkins, Calvin. 2005. Robert Rauschenberg's New Life. The New Yorker, May 23, 76.

Van Bruggen, Coosje. 1998. Frank O. Gehry: Guggenheim Museum Bilbao. New York: Guggenheim Museum Publications.

ZaeraPolo, Alejandro. 2006. Frank. O. Gehry: Still Life. In Frank Gehry, 1987-2003. Edited by Fernando Márquez Cecilia and Richard C. Levene. Madrid: El Croquis. 